\title{
WIRELESS-BASED EDUCATION INFORMATION SYSTEM IN MATARAM: DESIGN AND IMPLEMENTATION
}

\author{
Muhammad Tajuddin ${ }^{1}$ \\ Zainal AHasibuan ${ }^{2}$ \\ Abdul Manan ${ }^{3}$ \\ Nenet Natasudian Jaya ${ }^{4}$ \\ e-mail:judin61@yahoo.com,zhasibua@cs.ui.ac.id,mananmti@gmail,com, \\ natasu_diazella@yahoo.co.id.
}

Diterima : 19 Desember 2011 / Disetujui : 28 Desember 2011

\begin{abstract}
Education requires Information Technology (IT) for facilitating data processing, fastening data collecting, and providing solution on publication. It is to reach the Education National Standard which needs a research. The survey will use questionnaires as data collector for explanatory or confirmatory in constructing the System Development Life Cycle (SDLC) using structured and prototyping techniques, so a planning is by anticipating the changes. It comprises 5 subsystems; Human Resources, Infrastructures \& Equipment, Library, GIS Base School Mapping, and Incoming Students Enrollment. The construction is aimed to ease information access connected among schools, Education Service, and society, integrating and completing each other.
\end{abstract}

Key Words: System, Information, Education, and Wireless.

1. STMIK Bumigora Mataram West Nusa Tenggara

Jl. Ismail Marjuki Mataram, Nusa Tenggara Barat 83121

2. Lecture in Computer Science Department, University of Indonesia

J1. Salemba Raya 4 Jakarta 10430

3. PDE Office of Mataram City

Jl. Ismail Marjuki Mataram, Nusa Tenggara Barat 83121

4. ABA Bumigora Mataram

Jl. Ismail Marjuki Mataram, Nusa Tenggara Barat 83121

Vol.5 No.3 - Mei 2012 


\section{INTRODUCTION}

\section{Background}

National education functions to carry out capability and to build the people grade and character in the frame work of developing the nation, aims to improve student potentials for being faithful and pious human to The Great Unity God, having good moral, healthy, erudite, intelligent, creative, autonomous, and being democratic and credible citizen (Regulation of National Education System, 2003).

Education is also a key to improve knowledge and quality of capability to reach upcoming opportunity to take part in the world transformation and future development. How significant the education role is, so often stated as the supporting factor for economic and social development of the people (Semiawan, 1999). This important role has placed the education as the people need, so the participation in developing the education is very important (Tajuddin,M, 2005).

The improvement of education relevancy and quality in accordance with the needs of sustainable development is one of formulations in the National Work Meeting (Rakernas) of National Education Department (Depdiknas) in 2000. Result from the meeting is efforts to improve education quality in order that student possesses expertise and skill required by the job market after graduated (Hadihardaja, J, 1999).

All the efforts could not be immediately implemented but should follow phases in education fields subject to the regulations e.g. learning process to improve graduates quality, increment of foreign language proficiency especially English, and IT usage (Tajuddin M, 2004).

It is known that education and knowledge are important capitals to develop the nation. Their impact on the achieved development is unquestionable. Appearance of technology innovation results could change the way of life and viewpoint in taking life needs requirement of a nation. So it is concluded and proved that education provides strong influences to create changes on a nation (Wirakartakusumah, 1998).

The education system is in accordance with the national education system standard. Every educational institution must have its own condition, scope, and way of managing the education process. However, there is still similarity in management standard so quality provided by each educational institution is according to the conducted assessment standard (Slamet, 1999).

In the Government Rule (PP) No. 19, 2005, for Education National Standard $(S N P)$ in Chapter II Section of Education National Standard, comprises:

a. Standard of content;

b. Standard of process;

c. Standard of graduate competency; 
d. Standard of educator and educational staff;

e. Standard of infrastructure \& equipment;

f. Standard of management;

g. Standard of funding; and

h. Standard of evaluation.

For the eight education standards, it seems important to provide an information technology system to facilitate the information of infrastructure, education staff, library, etc., either on education unit level or on the government office level (Education Service), (Tajuddin M, 2007).

The education system sometimes integrated many related parts to combine its service performances. The involved parts are equipment, education staffs, curriculum, and so on. The mentioned parts are sectors taken in general from the common education systems. Integrated education system always fuses many parts to manage the process (Tajuddin M, 2006).

An education institution needs an integrated system which creating service system should be benefiting the schools, the Diknas, Local Government, and communities in occasion of transparency and accountability. Thus, the integrated education system has two main characteristics; the first is management process of internal system, and the second, is external service process. The internal management process aims to meet an effective system management process. Occurred here is an inter-section using data network structure existed in the educational environment (Miarso, 1999).

Each section is able to know the newest data of other sections that facilitating and more fastening the process of the other sections. Meanwhile, the external management process has more direction to the services for communities. This process aims to provide easy and rapid services on things connected with equipment and infrastructures of education. Integrated information system of education equipment and infrastructures offers many benefits such as:

1. Facilitating and modifying the system. An integrated system commonly comprises modules that separated each other. When system change occurred, adjustment of the application will easily and quickly perform. As the system change could just be handled by adding or reducing the module on application system.

2. Facilitating to make on-line integrated system. It means that the system could be accessed from any place, though it is out of the system environment. This on-line ability is easy to make because it is supported by the system integrated with the centered data. 
3. Facilitating the system management on the executive level. Integrated system enables executive board to obtain overall view of the system. So the control process could be easier and entirely executed (Leman, 1998).

Besides having those strengths, the integrated system has also weaknesses. Since the saved data is managed centrally, when data damage occurred, it will disturb the entirely processes. Therefore, to manage the database needs an administrator whose main function is to maintain and duplicate data on the system (Tajuddin M, 2005). Also, an administrator has another function to be a regulator of rights/license and security of data in an education environment, and so is in Mataram.

Department that responsible in education management in Mataram is the Diknas (National Education), supervises three Branch Head-offices of Education Service [Kepala Cabang Dinas (KCD)] those are KCD of Mataram, KCD of Ampenan, and $K C D$ of Cakranegara. Mataram has 138 state elementary schools $(S D N)$ with 40.604 students, 6 private elementary schools having 1.342 students. Meanwhile the state Junior school (SMPN) it has 21 schools with 15.429 students, and private junior school amounts to 8 schools having 1.099 students. It has 8 state high schools $(S M A N)$ having 5.121 students, 16 schools of private having 9.623 students, state vocational high school (SMKN) amounts to 7 schools having 4.123 students and the privates have 6 schools with 1.568 students (Profil Pendidikan, 2006).

In 2006, granted by the Decentralized Basic Education Project (DBEP), Mataram Education Service has wireless network connected with three sub-district Branch Offices of Service, those are Mataram, Ampenan, and Cakranegara, which will be continued in 2007 by connecting sub-district for Junior and High schools, and cluster for elementary schools. Three constructions of wireless network will be built in 2007 for high school sub-rayon, 6 constructions for junior school sub-rayon, and 15 constructions for elementary school cluster; the total is 24 wireless network connections for schools and three for the KCDs. (RPPK, 2007). To know the wireless network constructed in supporting the education system of Mataram, it needs development of an education information system that integrated each other in a system named Education Information System of Mataram. So the data and information access, either for schools, Diknas, and community could be executed swiftly in occasion of improving education services in Mataram based on the information technology or wireless network. 


\section{PROBLEM FORMULATION}

From the above background, problems could be formulated as follow: "Is the Design Construction of School Base Education Information Using Wireless Network in Mataram able to process the education information system rapidly, properly, and accurately in improving the educational services?"

\section{PURPOSE OF RESEARCH}

1. Procuring information system application integrated between one subsystem with others which will provide the following data on educational units:

- Data of number of teacher and their functional position on respective educational unit, and number of elementary school class teacher, and number of teacher per class subject for junior and high school.

- Data of student available on the detail education units.

- Data of number of classroom, furniture, laboratory, educational media, sport equipment available on the education units.

- Data of library on the respective educational unit.

- Data of school location respectively using GIS.

- Data of incoming student registration for the transparency and accountability of incoming students enrollment.

2. Unified data from the respective educational unit entirely on the Mataram local government level especially the Education Service of Mataram.

3. Processed data on the Education Service of Mataram to be an education management information system of Mataram.

\section{METHOD OF RESEARCH}

\section{Kind of Research}

The conducted kind of research is survey research that is by taking samples from population using questionnaires as a suitable data collecting tool (Singarimbun, 1989). This survey research is for explanatory or confirmatory in which provides explanation on the relation of inter-variables through research and examination as formulated previously.

\section{Location of Research}

Research is located on schools in Mataram covering state and private elementary schools which data access directly to the $K C D$ s, and the state and private junior and high schools which directly accessed to the Education Service of Mataram. 


\section{Procedure of Data Collecting and Processing}

Data is collected in the way of:

- Interview with source who is a leader such as schoolmaster, head of education branch office, or education service head-office of Mataram.

- Documentation, provided is books contained procedures and rules of education equipment and infrastructures, functional positions, etc.

- Questionnaires, disseminated on the Education Service of Mataram prior to wireless network preparation, the questionnaires will be containing questions of data flow diagram, hardware or software used, etc.

- Observation, learning the data flow diagram. It is implemented from data collecting, processing until documenting and reporting processes.

\section{Data Analysis}

\section{a. System Planning}

It uses methodology of System Development Life Cycle (SDLC) by structured and prototyping techniques. Presently as analyzed, the education service has some departments having self-working, it makes the process is taking longer time. This new system enables each department of education subsystem connected each other; it makes each of them know the available information. To keep the data security, there should be ID Number for every department or personnel involved as password to access into the related departments.

\section{b. Validity Examination and Sense Analysis}

Analysis on the information system comprises:

- Filling-out procedure of education data

- Processing procedure of education data

- Reporting procedure of education data

\section{c. System Analysis, covering:}

- Need analysis to produce system need specification

- Process analysis to produce:

- Context Diagram

- Documentation Diagram

- Data Flow Diagram(DFD)

- Data analysis to produce:

- Entity Relationship Diagram(ERD)

- Structure of Data 
The system analysis aims to analyze the running system to understand the existing condition. This analysis usually uses document flow diagram. The flow of document from one department to another can be seen obviously, as well as is the manual data savings. This process analysis is also used on the equipment and infrastructures. Results of this analysis then are used to design information system as required, to make an "Informative System Construction ".

RESULT AND DISCUSSION

\section{Construction of Wireless Network}

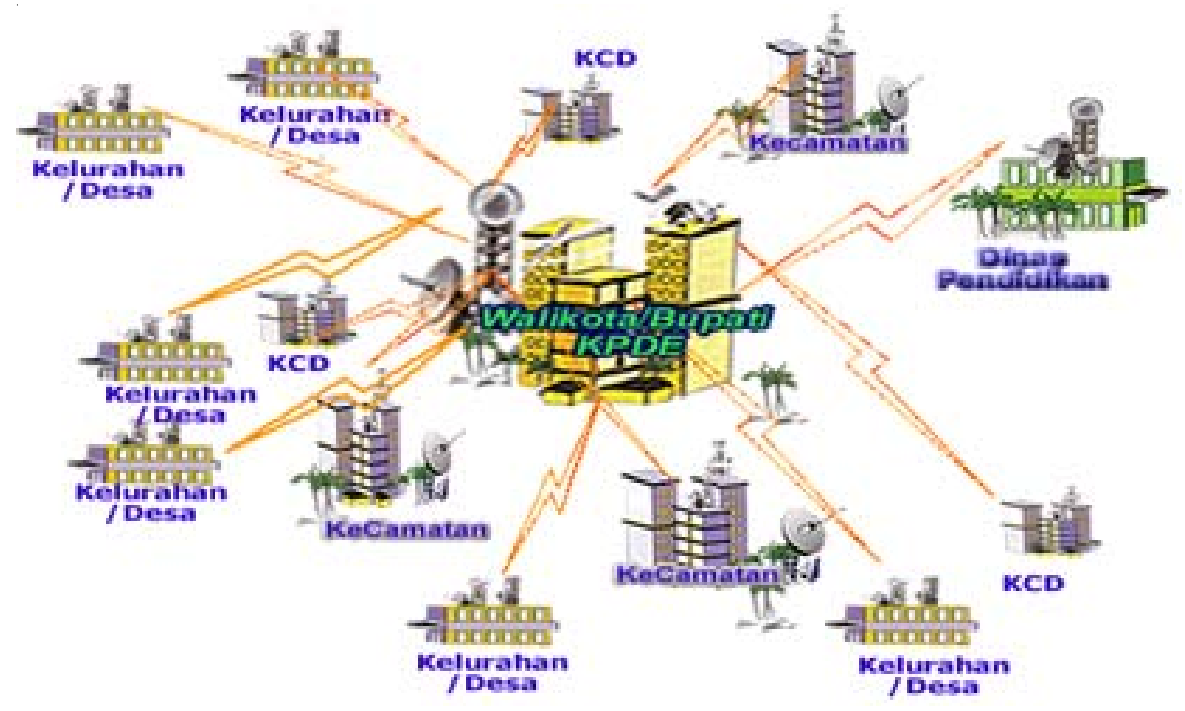

Chart 1. Construction of Wireless Network

\section{Development of Hardware}

- Addition of the Triangle facility on the Education Service office of Mataram as the central of management.

- Addition of antenna and receiver radio at the respective cluster on elementary school, 9 units for each sub-district and 3 units for the cluster leaders.

- Procurement of 6 units of antenna and receiver radio at the respective subdistrict of junior schools for the sub-district leaders.

- Procurement of 6 units of antenna and receiver radio, 2 units for each subdistrict of high schools in 2007. 


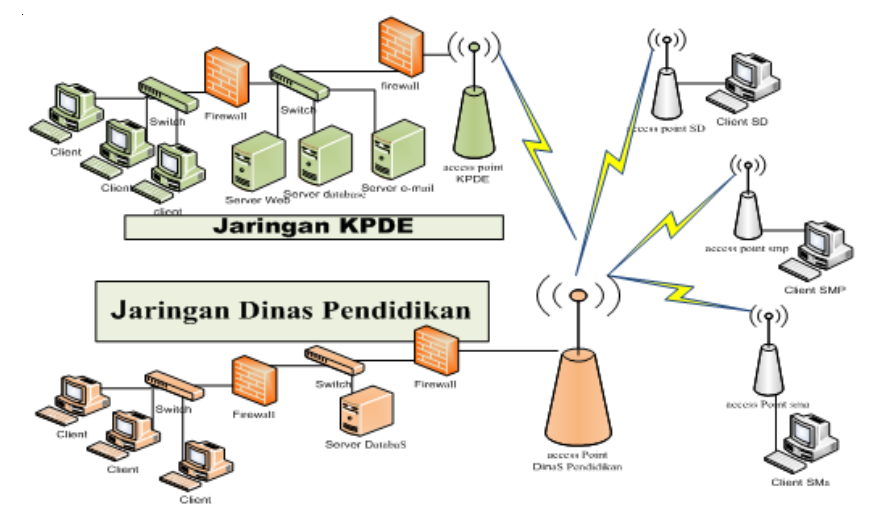

Chart 2.. Hardware network

\section{Development of Software}

- Mataram Area Network (MAN) Base incoming student enrollment.

- School base education equipments and infrastructures.

- School base functional position of teachers.

- Geographic Information System(GIS) base school mapping.

\section{Development Model Design}

\section{a. System Development}

Problem solution and user needs fulfillment are the main purpose of this development. Therefore, in the development should be noticed the information system principles, those are:

1. Involving the system users.

2. Conducting work phases, for easier management and improving effectiveness.

3. Following the standard to maintain development consistency and documentation.

4. System development as the investment.

5. Having obvious scope.

6. Dividing system into a number of subsystems, for facilitating system development.

7. Flexibilities, easily further changeable and improvable.

Besides fulfilling the principles, system development should also apply information system methodology. One of the methodologies and very popular is System Development life Cycle (SDLC), using structured and prototyping techniques. 


\section{b. Implementation}

This phase is commenced on making database in SQL by conversing database into tables, adding integrates limitations, making required functions and view to combine tables. Application software is using PHP language to access the database. Information system process of credit point determining enumeration is the important process on this module.

\section{a. Means and Infrastructure Information System Prime Display}

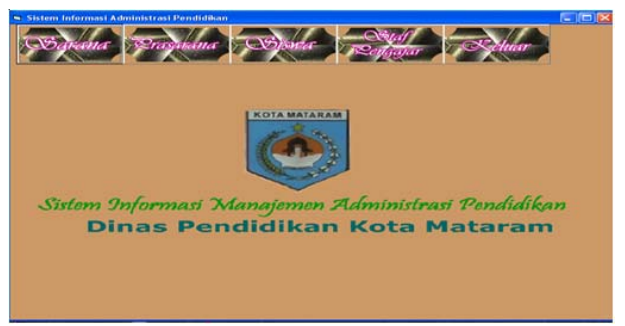

Figure3. Prime Display of SIMAP Mataram.

\section{Data Input Menu}

Data Input Menu is used to put means and infrastructure for elementary schools data by the $K C D$ of the respective sub-district, while for junior and high schools is done by the respective available educational unit.

As seen at the following Figure:

1. Means of education data input:

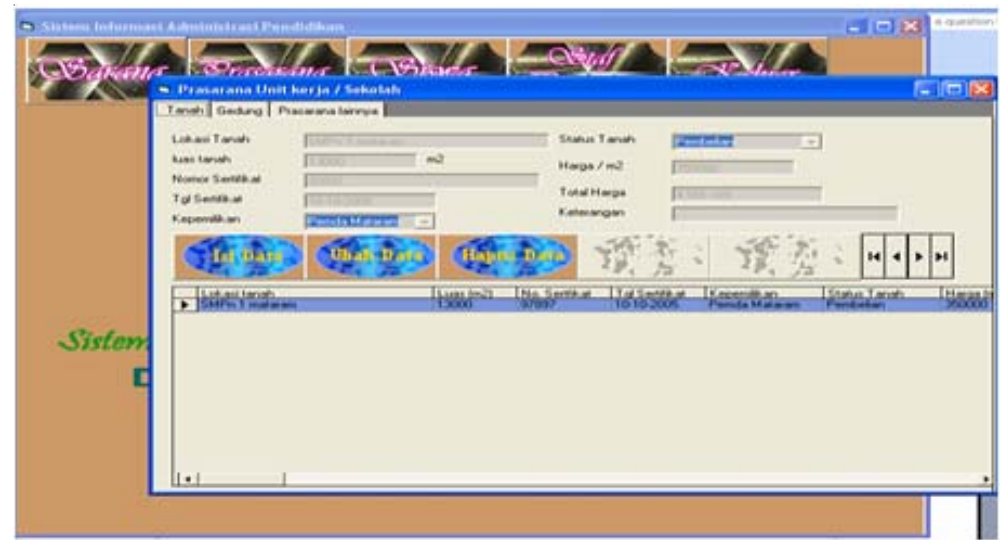

Figure 4 Means of education data input 
2. Data input of teacher profile on the education unit

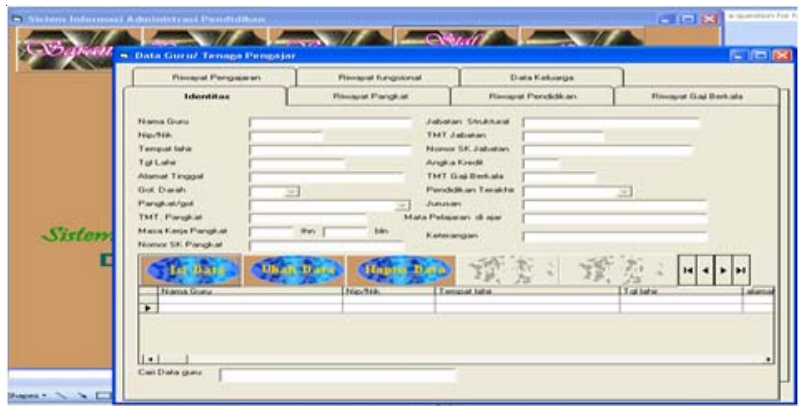

Figure 5. Educational staff (teacher)

3. Land infrastructure data input

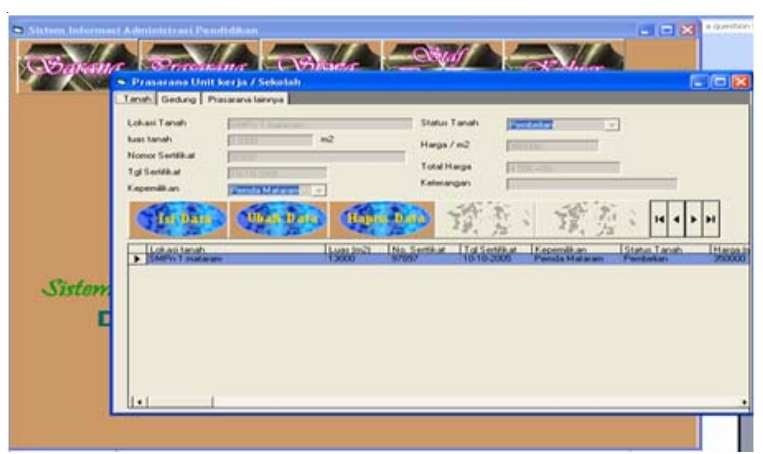

Figure 6. Land infrastructure data

4. Land infrastructure data input

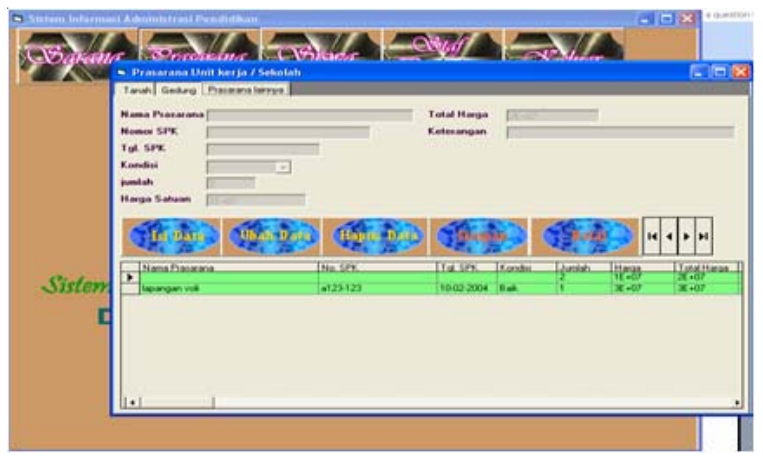

Figure 7. Land infrastructure data. 
5. Student data input

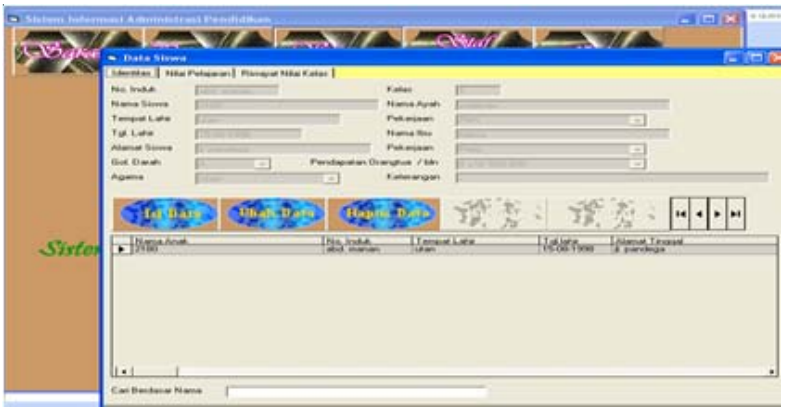

Figure 8. Student data input

Input design is a data display designed to receive data input from user as the data entry administrator. This input design should have clarity for users, either of its sort or its data to put in. Meanwhile, input design of the Credit Point Fulfillment System has 2 designs: Curriculum Vitae and obtained credit points.

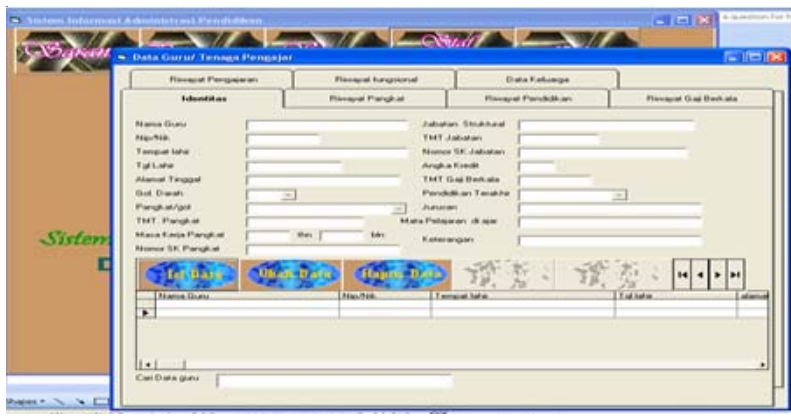

Figure 9. Teacher/instructor identity data input

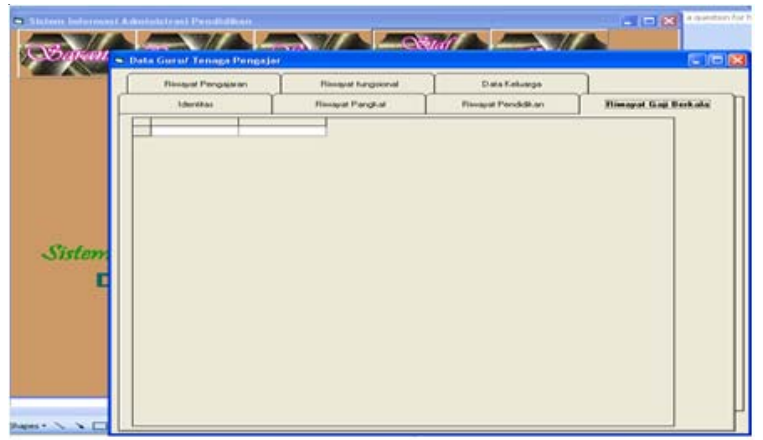

Figure 10. Teacher/instructor resume data input 


\section{B. Library Information System}

\section{Prime Menu of Library Information System}

It displays various menus of procurement, processing, tracing, membership and circulation, rule catalogue, administration and security. This menu display could be setup according to the user access (privilege), such as could only activate the trace menu for public users, as shown on the Figure below:

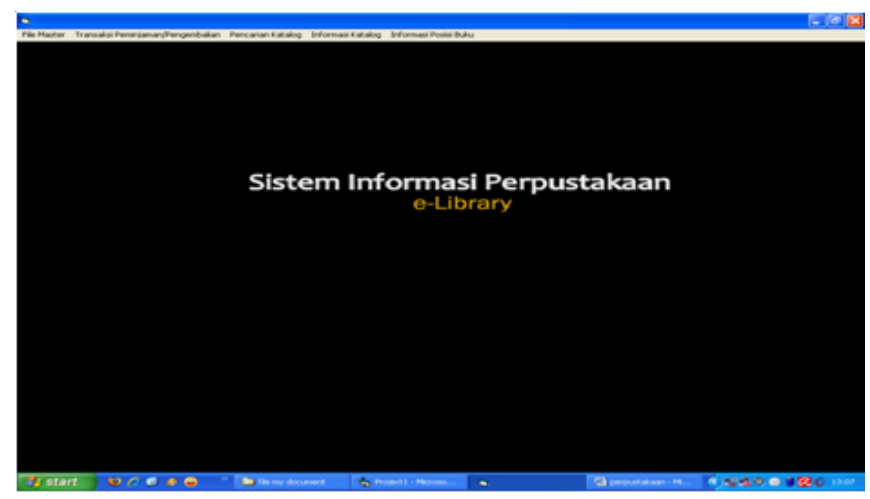

Figure 11. Prime menu of Library Information System

\section{Administration, Security, and Access Limitation}

This feature accommodates functions to handle limitation and authority of users. It classifies users and provides them identification and password. And also it provides self-access management, development, and processing as required.

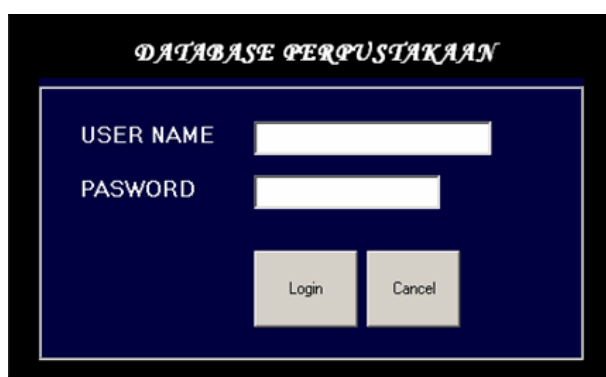

Figure 12. Key-word facility

\section{Reference Procurement}

This feature accommodates functions to record request, ordering, and payment of references, including the acceptance and reporting the procurement process. 


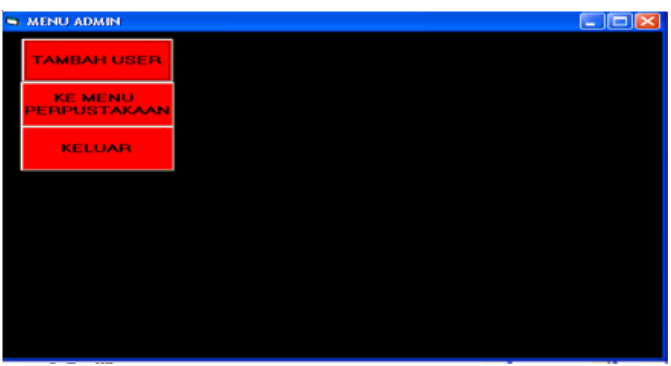

Figure 13. Administrator menu facility

\section{Reference Processing}

This feature accommodates input process of book/magazine to the database, status tracing of the processed books, barcode input of book/number cover, making catalogue card, barcode label, and book call number.

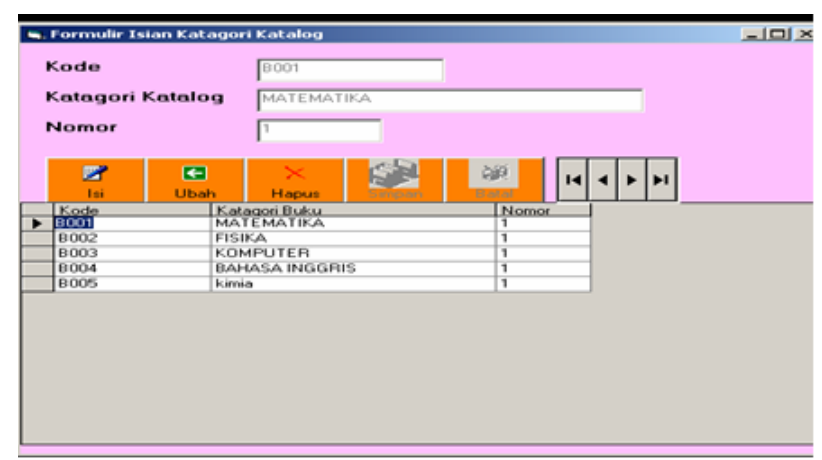

Figure 14. Catalogue category data input facility

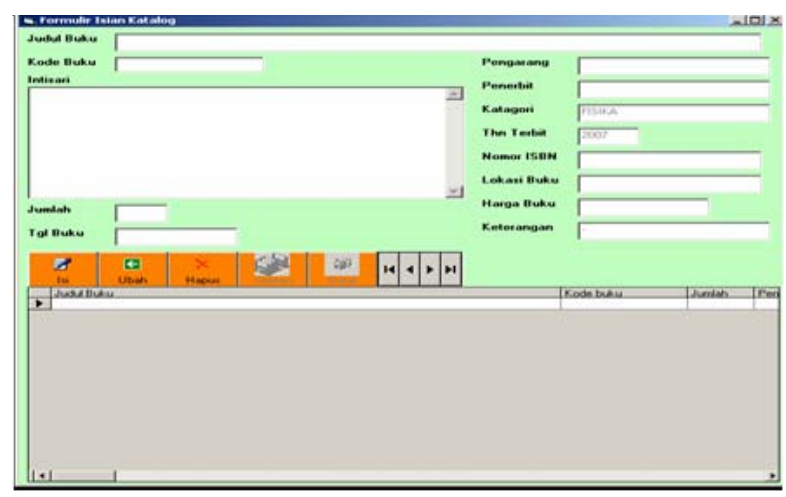

Figure 15. Catalogue data input facility 


\section{Reference Tracing}

Tracing or re-searching of the kept collections is an important matter in the library. This feature accommodates tracing through author, title, publisher, subject, published year, etc.

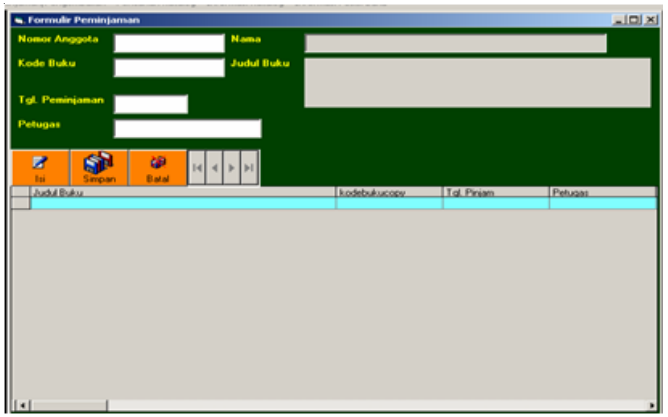

Figure 16. Borrowing data input facility

\section{Management of Member and Circulation}

It is the center-point of the library automatic system, because here are many manual activities replaced by the computer. Available inside is various features i.e. input and search of library member data, record of book borrowing and returning (using barcode technology), fine calculating for delay book return, and book ordering.

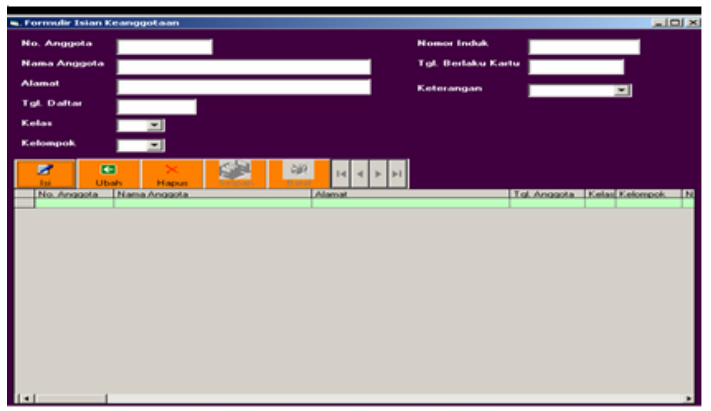

Figure 17. Borrower's return catalogue facility

\section{Reporting}

Reporting system eases librarian to work faster, in which report and recapitulation is automatically made as managed parameter. It is very helpful in analyzing library activity processes, such as the librarian does not need to open thousands of transaction manually to find the collection borrowing transaction of one category, or to check a member's activity for a year. 


\section{CONCLUSION}

The Construction of School Base Education Information Using Wireless Network in Mataram is an integrated hardware and software in supporting education, comprises some modules such as:

1. Education equipment and infrastructures such as land, building, sport field, etc.

2. Educators and educational supporting staffs.

3. Students data on each educational unit

4. Data of teacher's functional position on education unit and on level of Mataram Education Service.

5. On-line system of Incoming Students Acceptance

6. E-learning base learning.

\section{REFERENCES}

1. Alexander, 2001. Personal Web Server. http://www.asp101.com/.

2. Anonim, 2003. Undang-Undang No.20 tahun 2003 tentang Sistem Pendidikan Nasional.

3. Anonim, 2005. Buku Saku Data dan Informasi, TK,SD,SMP,SMA dan SMK Kota Mataram, Dinas Pendidikan Kota Mataram Sub Bagian Perencanaan, Mataram.

4. Anonim, 2005. Profil Kota Mataram, Pemerintah Kota Mataram NTB.

5. Anonim, 2003. Pengumpulan dan Analisi Data Sistem Informasi Sumber Daya Manusia, PT. Medal Darma Buana, Pengembangan Intranet LIPI

6. Anonim, 2005. RencanaPengembangan Pendidikan Kota Mataram, Dinas Pendidikan Kota Mataram Sub Bagian Perencanaan..

7. Anonim, 2005. Peraturan Pemerintah Nomor 19 Tentang Standar Nasional Pendidikan (SNP).

8. Curtis G.1995 Bussines Information System Analysis, Design and Practice, $2^{\text {rd }}$ Edition. Addison Wesley.

9. DEPARPOSTEL, 1996. Nusantara-2, Jalan Raya Lintasan Inforamasi : Konsep dan visi masyarakat inforamasi nasional. Deparpostel, Jakarta.

10. Hadihardaja, J., 1999. Pengembangan Perguruan Tinggi Swasta. Raker Pimpinan PTN Bidang Akademik, Koordinator Kopertis, dan Direktur Politeknik Jakarta 28-30 November 1999.

11. Hendra dan Susan Dewichan, 2000. Dasar - dasar HTML. hendra@indoprog.com.

12. Hendra dan Susan Dewichan, 2000. Tutorial Java Script,http:// indoprog.terrashare.com/. 
13. Http://www.informatika.lipi.go.id/perkembangan-teknologi-informasi-diindonesia/ dibuka pada tanggal 8 Maret 2006.

14. Kendall, J., 1998. Information System Analysis. Perntice Hall.

15. Kendall Kenneth E., Kendall Julie E.1995, Systems Analysis and Design, Prentice Hall, 3rd Edition.

16. Leman., 1998. Metologi Pengembangan Sistem Informasi, Elekmedia Komputindo Kelompok Gramedia, Jakarta.

17. Miarso,Yusufhadi, 1999, Penerapan Teknologi Pendidikan di Indonesia, Universitas Terbuka, Jakarta.

18. Singarimbun, Masri dan Sofian Effendi,1986, Motede Peneletian Survey, LP3ES, Jakarta.

19. Slamet,Margono,1999, Filosofi Mutu dan Penerapan Perinsip-Perinsip Manajemen Mutu, Terpadu, IPB Bogor.

20. Tajuddin,M.,A Manan,Agus P,Yoyok A, 2007. Rancang Bangun Sisitem Informasi Sarana Prasarana Pendidikan Berbasis Sekolah Secara Online di Kota Mataram dan Lombok Barat, Procedings, Nacsit Universitas Indonesi, Jakarta.

21. Tajuddin,M.,Abdul Manan, 2006. Rancangan Sistem Informasi Sumber Daya Manusia (SISDM) Berbasis Jaringan Informasi Sekolah, Jurnal Matrik, STMIK Bumigora Mataram NTB.

22. Tajuddin,M., Abdul Manan, 2005. Desain dan Implementasi Sistem Informasi Manajemen Perguruan Tinggi Swasta Berbasi Web di STMIK Bumigora Mataram, Jurnal Matrik STMIK Bumigora Mataram NTB.

23. Tajuddin,M.,A Manan, 2005. Sistem Informasi Pemasaran Pariwisata Kabupaten Lombok Barat Menggunakan Internet, Jurnal Matrik STMIK Bumigora Mataram NTB.

24. Tajuddin,M.Abdul Manan,2004. Rancangan dan Desain Sistem Informasi Manajemen Perguruan Tinggi Swasta Berbasi Web di STMIK Bumigora Mataram, Valid Akademi Manajemen Mataram NTB.

25. Tajuddin,M.,2003. Penggunaan Multi Media dan Sibernetik Untuk Meningkatkan Kemampuan Mahasiswa, Jurnal Matrik STMIK Bumigora Mataram NTB.

26. Tirta K. Untario. 2000. ASP Bahasa Pemrograman Web.htt:// www.aspindonesia.net/.

27. Wijela, R. Michael, 2000. Internet dan Intranet. Penerbit Dinastindo, Jakarta.

28. Wirakartakusumah,1998, Pengertian Mutu dalam Pendidikan, Lokakarya MMT IPB, Kampus Dermaga Bogor, 2-6 Maret. 